\title{
Front Matter: Volume 10062
}

, "Front Matter: Volume 10062," Proc. SPIE 10062, Optical Interactions with Tissue and Cells XXVIII, 1006201 (24 March 2017); doi: 10.1117/12.2276121

SPIE. Event: SPIE BiOS, 2017, San Francisco, California, United States 


\section{PROGRESS IN BIOMEDICAL OPTICS AND IMAGING}

\section{Optical Interactions with Tissue and Cells XXVIII}

\section{E. Duco Jansen}

Hope Thomas Beier

Editors

30-31 January 2017

San Francisco, California, United States

Sponsored and Published by

SPIE 
The papers in this volume were part of the technical conference cited on the cover and title page. Papers were selected and subject to review by the editors and conference program committee. Some conference presentations may not be available for publication. Additional papers and presentation recordings may be available online in the SPIE Digital Library at SPIEDigitallibrary.org.

The papers reflect the work and thoughts of the authors and are published herein as submitted. The publisher is not responsible for the validity of the information or for any outcomes resulting from reliance thereon.

Please use the following format to cite material from these proceedings:

Author(s), "Title of Paper," in Optical Interactions with Tissue and Cells XXVIII, edited by E. Duco Jansen, Hope Thomas Beier, Proceedings of SPIE Vol. 10062 (SPIE, Bellingham, WA, 2017) Sevendigit Article CID Number.

ISSN: 1605-7422

ISSN: 2410-9045 (electronic)

ISBN: 9781510605657

ISBN: 9781510605664 (electronic)

Published by

SPIE

P.O. Box 10, Bellingham, Washington 98227-0010 USA

Telephone +1 3606763290 (Pacific Time) · Fax +1 3606471445

SPIE.org

Copyright @ 2017, Society of Photo-Optical Instrumentation Engineers.

Copying of material in this book for internal or personal use, or for the internal or personal use of specific clients, beyond the fair use provisions granted by the U.S. Copyright Law is authorized by SPIE subject to payment of copying fees. The Transactional Reporting Service base fee for this volume is $\$ 18.00$ per article (or portion thereof), which should be paid directly to the Copyright Clearance Center (CCC), 222 Rosewood Drive, Danvers, MA 01923. Payment may also be made electronically through CCC Online at copyright.com. Other copying for republication, resale, advertising or promotion, or any form of systematic or multiple reproduction of any material in this book is prohibited except with permission in writing from the publisher. The CCC fee code is $1605-7422 / 17 / \$ 18.00$.

Printed in the United States of America.

Publication of record for individual papers is online in the SPIE Digital Library.

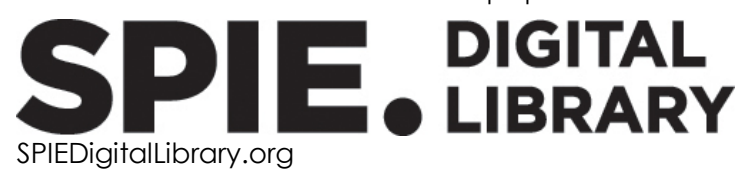

Paper Numbering: Proceedings of SPIE follow an e-First publication model. A unique citation identifier (CID) number is assigned to each article at the time of publication. Utilization of CIDs allows articles to be fully citable as soon as they are published online, and connects the same identifier to all online and print versions of the publication. SPIE uses a seven-digit CID article numbering system structured as follows:

- The first five digits correspond to the SPIE volume number.

- The last two digits indicate publication order within the volume using a Base 36 numbering

system employing both numerals and letters. These two-number sets start with 00, 01, 02, 03, 04, 05, 06, 07, 08, 09, OA, OB ... 0Z, followed by 10-1Z, 20-2Z, etc. The CID Number appears on each page of the manuscript. 


\title{
Contents
}

\author{
vii Authors \\ ix Conference Committee
}

\section{SESSION 1 ULTRAFAST PULSED LASER INTERACTION}

1006203 Evidence of femtosecond-laser pulse induced cell membrane nanosurgery [10062-2]

1006204 In-vitro photo-translocation of antiretroviral drug delivery into TZMbl cells [10062-3]

1006205 Targeted femtosecond laser driven drug delivery within HIV-1 infected cells: in-vitro studies [10062-4]

1006206 Phototransfection of mouse embryonic stem cells with plasmid DNA using femtosecond laser pulses [10062-5]

\section{SESSION 2 SHORT PULSED LASER EFFECTS}

1006207 Investigation of the efficacy of ultrafast laser in large bowel excision [10062-6]

1006208 Supra-threshold epidermis injury from near-infrared laser radiation prior to ablation onset [10062-7]

1006209 Direct numerical simulation of microcavitation processes in different bio environments [10062-8]

10062 OA All-fiber laser at $1.94 \mu \mathrm{m}$ : effect on soft tissue [10062-9]

\section{SESSION 3 PHOTOTHERMAL INTERACTIONS FROM PULSED LASERS}

10062 OB Pressure generation during neural stimulation with infrared radiation (Invited Paper) [10062-10]

$100620 \mathrm{C}$ Short pulse laser induced thermo-elastic deformation imaging [10062-11]

10062 OD Short infrared laser pulses increase cell membrane fluidity [10062-12]

10062 OF Antivascular effect induced by photo-mediated ultrasound [10062-14] 
10062 ol Correlating measured transient temperature rises with damage rate processes in cultured cells [10062-17]

10062 J Laser driven short-term thermal angioplasty: enhancement of drug delivery performance by heating with tension [10062-18]

\section{SESSION 5 PHOTOCHEMICAL AND PHOTO-OXIDATIVE INTERACTIONS}

10062 OL Photosensitization reaction induced hemolysis in a cuvette observed with hemoglobin absorption spectrum of various species [10062-20]

10062 ON Evaluation of electrical propagation delay with cardiomyocytes by photosensitization reaction in vitro [10062-22]

1006200 Extracellular talaporfin sodium-induced photosensitization reaction with various albumin animal species on myocardial cells in vitro [10062-23]

\section{SESSION 6 NOVEL APPLICATIONS OF LASERS AND LIGHT IN BIOMEDICINE}

10062 OT Using laser induced breakdown spectroscopy and acoustic radiation force elasticity microscope to measure the spatial distribution of corneal elasticity [10062-28]

\section{SESSION 7 NUMERICAL APPROACHES SIMULATING LASER-TISSUE INTERACTIONS}

10062 OW Analysis of nanoparticles optical propagation influence in biological tissue simulating phantoms [10062-31]

10062 OY Simulation analysis of the transparency of cornea and sclera [10062-33]

SESSION 8 OPTICAL PROPERTIES OF TISSUES

1006210 Study of the effect of temperature on the optical properties of Latin skins [10062-35]

POSTER SESSION

1006212 Multiple scattering of polarized light in uniaxial turbid media with arbitrarily oriented linear birefringence [10062-37]

1006214 The underlying structure of skin wrinkles: a hyperspectral approach to crows feet [10062-39]

1006216 Monte Carlo mathematical modeling of the interactions between light and skin tissue of newborns [10062-41] 
1006217 In vivo monitoring laser tissue interaction using high resolution Fourier-domain optical coherence tomography [10062-42]

$100621 \mathrm{~A}$ Pros and cons of characterising an optical translocation setup [10062-46]

$10062 \mathrm{lB}$ The role of numerical aperture in efficient estimation of spatially resolved reflectance by a Monte Carlo light propagation model [10062-47]

10062 1C Preservation media analysis for ex vivo measurements of endogenous UV fluorescence of liver fibrosis in bulk samples [10062-48]

$100621 \mathrm{~F}$ Increasing the quality and germination gymnosperms by photonics methods [10062-51] 
Proc. of SPIE Vol. 10062 1006201-6

Downloaded From: https://www.spiedigitallibrary.org/conference-proceedings-of-spie on 25 Apr 2023 Terms of Use: https://www.spiedigitallibrary.org/terms-of-use 


\section{Authors}

Numbers in the index correspond to the last two digits of the seven-digit citation identifier (CID) article numbering system used in Proceedings of SPIE. The first five digits reflect the volume number. Base 36 numbering is employed for the last two digits and indicates the order of articles within the volume. Numbers start with 00, 01, 02, 03, 04, 05, 06, 07, 08, 09, OA, OB...0Z, followed by 10-1Z, 20-2Z, etc.

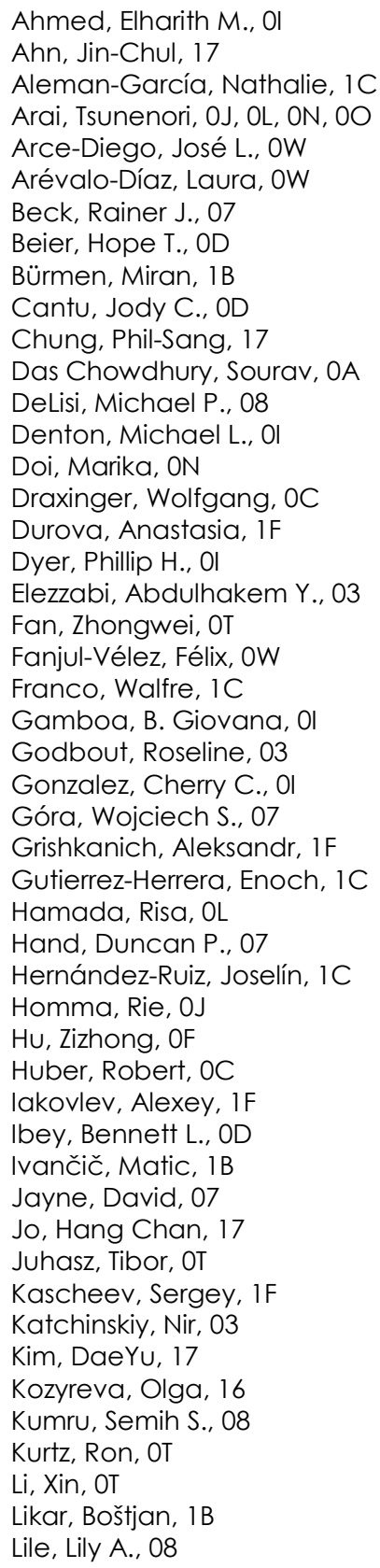

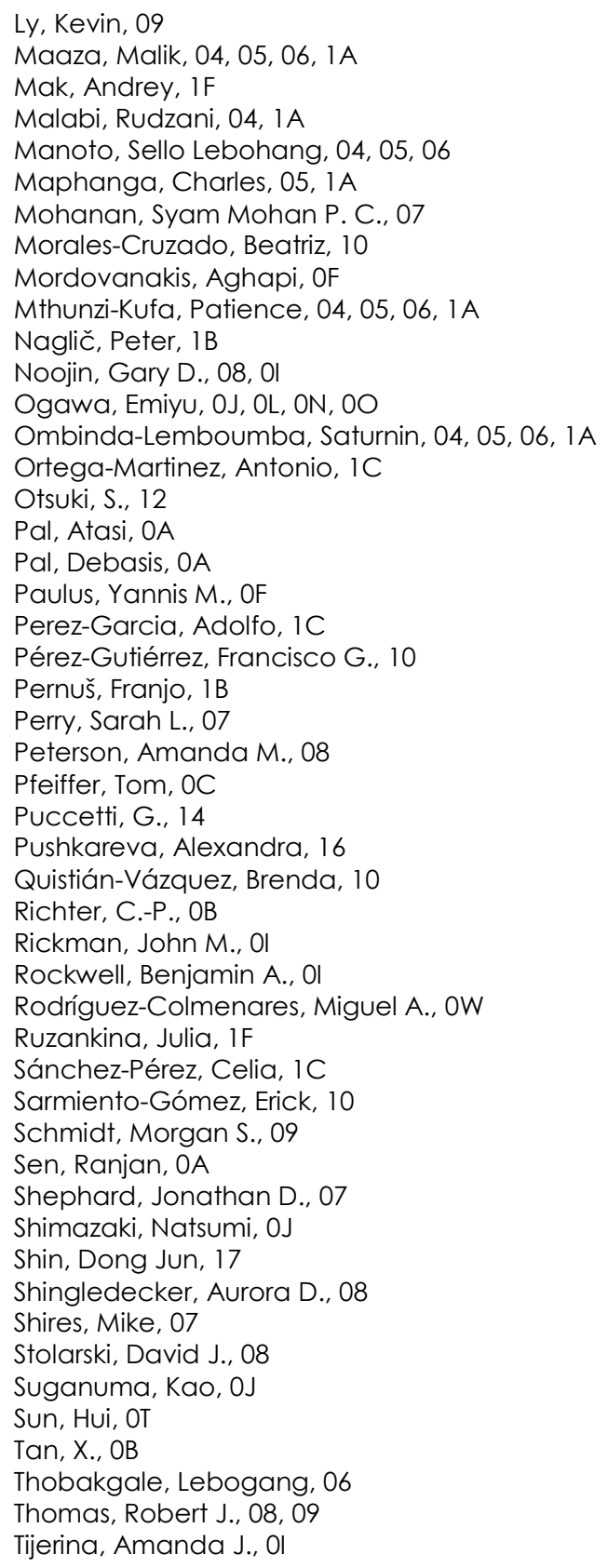


Tseng, Snow H., OY

van der Steen, Antonius F. W., OC

van Soest, Gijs, OC

Walsh, Alex J., OD

Wang, Tianshi, OC

Wang, Xueding, OF

Wen, Sy-Bor, 09

Wieser, Wolfgang, OC

Wu, Min, OC

Xia, N., OB

$X U, Y$., OB

Yang, Chih-Yao, OY

Yang, Xinmai, OF

Zhang, Haonan, OF

Zohner, Justin J., 08 


\section{Conference Committee}

Symposium Chairs

James G. Fujimoto, Massachusetts Institute of Technology

(United States)

R. Rox Anderson, Wellman Center for Photomedicine, Massachusetts General Hospital (United States) and Harvard School of Medicine (United States)

Program Track Chair

Steven L. Jacques, Oregon Health \& Science University (United States)

Conference Chairs

E. Duco Jansen, Vanderbilt University (United States)

Hope Thomas Beier, Air Force Research Laboratory (United States)

Conference Program Committee

Randolph Glickman, The University of Texas Health Science Center at San Antonio (United States)

Steven L. Jacques, Oregon Health \& Science University (United States)

Bennett L. Ibey, Tri Service Research Laboratory (United States)

Beop-Min Kim, Korea University (Korea, Republic of)

Alexander J. Makowski, Prozess Technologie (United States)

Jessica C. Ramella-Roman, Florida International University

(United States)

Marissa Nicole Rylander, Virginia Polytechnic Institute and State

University (United States)

Zachary D. Taylor, University of California, Los Angeles (United States)

Robert J. Thomas, Air Force Research Laboratory (United States)

Alfred Vogel, Universität zu Lübeck (Germany)

Gerald J. Wilmink, WiseWear Corporation (United States)

Session Chairs

1 Ultrafast Pulsed Laser Interaction

Hope Thomas Beier, Air Force Research Laboratory (United States)

2 Short Pulsed Laser Effects

Joel N. Bixler, Air Force Research Laboratory (United States) 
3 Photothermal Interactions from Pulsed Lasers

Bennett L. Ibey, Tri Service Research Laboratory (United States)

4 Photothermal Interactions

Randolph D. Glickman, The University of Texas Health Science Center at San Antonio (United States)

5 Photochemical and Photo-oxidative Interactions

Morgan S. Schmidt, Air Force Research Laboratory (United States)

6 Novel Applications of Lasers and Light in Biomedicine

Alexandra J. Walsh, Air Force Research Laboratory (United States)

$7 \quad$ Numerical Approaches Simulating Laser-Tissue Interactions

Benjamin A. Rockwell, Air Force Research Laboratory (United States)

8 Optical Properties of Tissues

Michael L. Denton, Air Force Research Laboratory (United States) 